\title{
LEGAL POLITICS OF DEVELOPMENT AND INDUSTRIAL EMPOWERMENT LAW IN INDONESIA
}

\author{
Ahmad \\ Faculty of Law, Universitas Muhammadiyah Tangerang \\ ahmad.law17@gmail.com
}

\begin{abstract}
Industrialization is an economic activity that processes raw materials or utilizes industrial resources to produce goods that have high values or benefits to the community and include industrial services. Industrial Law regulates all industrial activities that provide protection, guarantees and benefits for industrial activities by regulating the direction of development policies and industrial empowerment in realizing the greatest prosperity for the community. The research method used in this study was normative legal research with a descriptive analysis approach. The results showed that industrial law aimed at forming a just and prosperous national economic structure through setting the direction of development policies and empowering industries in the small and medium industry, green industries, strategic industries, and the use of domestic products and international cooperation.
\end{abstract}

Keywords: Industrial Law, Development, Empowerment, Prosperity.

Journal History

Received : September 09, 2020;

Reviewed : October 12, 2020;

Accepted : October 28, 2020;

Published : November 1, 2020

Copyright @2020 NLR. All right reserved. 


\section{INTRODUCTION}

Today's industrialization of the economy has a form of economic activity carried out by companies in managing raw goods, raw materials, semi-finished or finished goods to be made of goods that are of higher use so that they need to be regulated by law in order to provide fair protection, assurance and certainty of the interests public and could be subject to sanctions for any violation that harms the public interest.

According to Bhima Yudhistira, an economic observer from the Institute for Development of Economics and Finance (INDEF), stated that industrial problems in Indonesia were hampered by structural problems such as investment, competitiveness, human resources. For example, Porsi Investasi Penanaman Modal Dalam Negeri (PMDN) or in English as The Portion of Domestic Investment in the service sector rose significantly from $37.8 \%$ in 2016 to $45.6 \%$ in 2017. In fact, Porsi Investasi Penanaman Modal Asing (PMA) or in English as the Portion of Foreign Investment in the service sector jumped from $26.8 \%$ to $40.3 \%$ of the total investment. Meanwhile, the portion of investment in the manufacturing or manufacturing industry sector, both

\footnotetext{
1 Bhima Yudhistira, Sektor Industri Masih Hadapi Banyak Permasalahan Struktural (Industrial Sector Still Faces Many Structural Problems),
}

foreign and domestic investment continues to decline from $54.8 \%$ in 2016 to $39.7 \%$ in 2017. While Indonesia's industrial sector's competitiveness is currently lagging behind that from neighboring countries, such as Vietnam and Thailand. For instance the textile industry in Indonesia is less productive because the machinery used is old and "This condition also occurs in several other strategic industrial sectors". Likewise, the industrial sector will also not be able to grow significantly if the available human resources are mostly only junior high school graduates because now the portion of the workforce of junior high school graduates reaches $70 \%$ of the total workforce. ${ }^{1}$

Economic globalization has created a lot of changes to various forms of new events in the development of the world economy, namely the occurrence of the era of the international free market, interdependence of the system, both in the political and economic fields, the various international economic institutions, the grouping of countries in regional economic zones, the rapid advancement of Trans National Corporation economic actors, the birth of the Military Industrial Complex and so on. This cannot be carried out in a legal vacuum and the

https://ekonomi.bisnis.com/read/201803 31/257/778398/sektor-industri-masihhadapi-banyak-permasalahan-struktural. 
legal methods are highly treated to regulate the mechanism of relations so as not to become a conflict of interest in the economic development of a nation. If a conflict does occur, the legal framework can be used as a tool to resolve it. The law in addition to maintaining public order, can also be used as a guide in economic development so that there is legal certainty and a sense of justice for economic actors wherever they are. ${ }^{2}$

The law does not stand alone and does not arise by chance, but is born from the inner awareness of the people, therefore the law develops along with the development of its people, and eventually it will disappear if the people lose their nationality. According to Savignya, if the law makers want to formulate law in technical juridical principles, then the legislators must remain positioned as organs of public awareness. Legislators are tasked with giving shape to what is found in raw materials. The raw material in the formation of law according to Savigny is the duty of legal scientists to provide it. While the legislators formulated technically in the form of formal rules. ${ }^{3}$

2 Abdul Manan, Makalah Peranan Hukum dalam Pembangunan Ekonomi (Legal Role Paper in Economic Development), (2012).

3 Muhammad Yusrizal Adi Syaputra, Dani Sintara,Revitalization of Malay Cultural Values in Regional Regulation of Spatial and Region in Medan City. Budapest International
The 3 (three) principles referred to include the lex superior de rogat lex inferior principle, lex specialist derogate lex generalis, lex posterior de rogat lex priori. Jazim Hamidi further explained that based on the study of legal science 3 (three) principles as referred to are important pillars in understanding the construction of statutory law in Indonesia in detail, it can be explained that: a) The principle of lex superior de rogat lex inferior, higher regulations will override lower regulation when regulating the same and conflicting substances. b) As a lex specialist derogat lex generalis principle, more specific rules will override general rules when regulating the same and contradictory substances. c) The principle of lex posterior de rogat lex priori, the new regulation will override the old regulation. ${ }^{4}$

Industrial Development is one of the main pillars of national economic development, which is directed by applying the principles of sustainable industrial development based on aspects of economic, social, cultural and environmental development. Currently industrial development is facing global competition which is very influential

Research and Critics Institute-Journal (BIRCI-Journal) Vol. 2, No. 3, August 2019, p. 355.

${ }^{4}$ Eka N.A.M Sihombing, Cynthia Hadita, Analisis Wacana Hukuman Pancung Di Provinsi Aceh, Jurnal Legislasi Indonesia, Vol. 6, No. 4, December (2019). 
on the development of national industries. Increasing industrial competitiveness is one of the choices that must be made so that national industrial products are able to compete both domestically and abroad. Steps in order to increase competitiveness and investment attractiveness, namely the creation of a conducive business climate, efficiency, legal certainty, and the provision of fiscal facilities and other facilities in industrial business activities, which include the availability of adequate industrial locations in the form of Regions Industry.

Based on the description as mentioned above, it becomes important and necessary to do research and study on industrial law by focusing on aspects of the direction of development policy and industrial empowerment so that all forms of economic industrialization activities, including the direction of development policy and industrial empowerment can be achieved as much as possible for the prosperity of the people .

\section{METHOD}

This type of research is library research the source of data obtained through research on various literature relevant to the object of research. As a research that traces the principles and concepts of law regarding Indonesian industrial law, this methodological study will examine the concepts of industrial law and its implementation in the direction of development policy and industrial empowerment. This is important because only from the concept of law can the meaning of the legal norms be found in the context of practice.

The type of this research is Descriptive Analytical Qualitative, meaning that the research is carried out by describing, analyzing qualitatively on data relating to the object of research both in positive law to draw conclusions in accordance with the subject matter.

\section{DISCUSSION}

\section{Indonesian Law}

Philosophically, industrial law is aspired as an effort to create a just and prosperous society that is independent, united and sovereign based on the principles of the Pancasila and the 1945 Constitution of the Republic of Indonesia by implementing national development with the principles of economic democracy. The implementation of national development in the economic field is intended in order to create a strong economic structure through the development of advanced industries in realizing an independent, healthy and competitive industrial structure as a driving force for the economy so that strong power and resource capabilities are needed. Utilizing resources optimally and efficiently as well as encouraging industrial development throughout the territory of Indonesia and at the same time maintaining the balance of progress 
and national economic unity based on national justice, justice and noble cultural values in accordance with national interests.

Indonesia is one of the countries in the world that adheres to a democratic political system which in its implementation wants the widest possible freedom of political participation for all people to take an active role in determining the direction of nation development. One of its roles is to determine the leader directly, publicly, freely and secretly through a general election. To achieve this, the Government is required to be able to facilitate the holding of elections as an effort to build democracy. ${ }^{5}$

Industry requires the existence of an order and all activities related to industrial activities while Industry is all forms of economic activities that process raw materials and / or utilize industrial resources to produce goods that have added value or benefits including the availability of industrial services. While the types of industries are known as green industries and strategic industries, both types of industries have different characteristics from each other. The green industry in its production process prioritizes efforts on efficiency and effectiveness of the use of resources in a sustainable manner that harmonizes industrial development with the preservation of environmental functions that provide benefits to the community. Whereas strategic industry is an industry that is important for the State and controls the lives of many people in an effort to increase or produce the value of strategic natural resources related to the interests of the defense and security of the State as the implementation of the tasks of the State government.

The principles of industry implementation are based on national interests, economic democracy, business certainty, equity, fair business competition in achieving the goal of realizing national industry as a pillar and driving force of the national economy in the form of depth and strength of the independent, competitive, advanced industrial structure, green industry so that business certainty must be realized, fair competition and prevent centralization or control of industry by one group or individual that harms the community by providing business opportunities and expansion of employment opportunities and realizing even distribution of industrial development throughout Indonesia to strengthen and strengthen national resilience in efforts to improve prosperity and welfare of the community in a just manner.

Pemilihan Umum Kepala Daerah Di Kota Medan, JurnalEduTech, Vol. 5, No.1 Maret 2019, p. 7. 
The scope of the regulation in industrial law covers the administration of government affairs in the field of industry, the master plan for national industry development, national industrial policy, industrial zoning, industrial resource development, industrial facilities and infrastructure development, industrial empowerment, industrial security measures and industrial rescue, licensing, investment of industry and facility bidnag, national industry committee, community participation, supervision and control.

The function of regulation, guidance and industrial development becomes the authority of the President as the organizer of the government at the central level, the Governor of the Provincial level and the Regent and / or Mayor at the Regency and or city level while the technical authority for certain industrial fields is carried out by the relevant ministries. In order to realize the objectives of industrial implementation, a master plan for national industrial development is prepared that is in line with the national long-term development plan and is also a guideline for the government and industry players in industrial planning and development which is prepared for a period of 20 (twenty) years and can be reviewed every 5 (five) years.

The master plan for national industrial development is prepared with the least regard to the potential of industrial resources, industrial culture and local wisdom that grows in the community, the potential and socio-economic development of the region, the development of industry and business, both national and international, the development of strategic environment, both national and international and national spatial plans, provincial spatial plans, and / or district / city spatial plans.

The master plan for national industrial development covers at least the vision, mission, and strategy of industrial development, the targets and stages of the achievement of industrial development, national industry development, development of industrial resources, construction of industrial facilities and infrastructure, industrial empowerment and industrial territory. the national industrial development master plan is prepared by the minister in coordination with relevant agencies and considers input from stakeholders related to the national industrial development master plan implemented through national industrial policies stipulated in government regulations.

Solly Lubis in Hadita (2020) The theory of power, Laski argues, along with Marx, namely that every association of life requires coercive instruments, thus claiming the continuation ofa permanentprodu ction relationship, because if it were not so then the association of life would not be able to claim its livelihood. By Plato in his book 
"Politeia" Thrasymachos statement noted, that justice is the interest of the powerful who demanded the arrangement to the power that is there, it means that the law and the interests

of the ruling is one. ${ }^{6}$

Mirza Nasution in Hadita (2020) The authoritarian political configuration, is the composition of the political system that allows the state to play a very active role and takes almost all initiatives in making state policy. This configuration is marked by the drive of the power elite to impose unity, the elimination of open opposition, the dominance of the state leadership to determine state policy, and the dominance of political power by the eternal political elite, and there is a doctrine that justifies the concentration of power. ${ }^{7}$

Each governor prepares a Provincial Industrial Development Plan with reference to the National Industrial Development Master Plan and National Industrial Policy by taking into account the potential of the regional Industrial resources, the Provincial Spatial Planning and / or Regency / City Regional Spatial Planning and the harmony and balance with the Industrial development policies in regencies / cities as well as socioeconomic activities and environmental carrying capacity.

${ }^{6}$ Cynthia Hadita, Regional Autonomy Political Politics Of Regional Liability Reports To Regional Representatives In The Implementation
Provincial

industrial development plans are stipulated by provincial regional regulations after being evaluated by the government in accordance with statutory provisions. Each regent /a mayor prepares a Regency / City Industrial Development Plan. Regency / City Industrial Development Plans are prepared by referring to the National Industrial Development Master Plans and National Industrial Policies with regard to the potential of regional Industrial resources, Provincial Regional Spatial Plans and Regency / City Regional Spatial Plans and harmony and balance with socioeconomic activities and resources support the environment, the Regency / City Industrial Development Plan is determined by Regency / City Regional Regulations after being evaluated by the governor in accordance with statutory provisions.

The National Industrial Policy is the direction and action to implement the Master Plan which includes the industrial development targets, the focus of industrial development, the stages of industrial development achievements, the development of industrial resources, the development of facilities and infrastructure, the development of industrial territories and fiscal and non-fiscal facilities. The National

Of Local Government, Nomoi Law Review, Volume 1, Issue 1, May 2020, p. 93.

${ }^{7}$ Ibid., p. 93. 
Industrial Policy is prepared for a period of 5 (five) years by the Minister in coordination with relevant agencies and considers input from relevant stakeholders. The National Industrial Policy is spelled out in the Industrial Development Work Plan prepared for a period of 1 (one) year by the Minister in coordination with relevant agencies and considers input from relevant stakeholders.

The efforts of the Government and / or Regional Governments in accelerating the spread and equitable distribution of industrial development to the entire territory of the Unitary Republic of Indonesia through the regional territorial industry by taking into account regional spatial plans, utilization of potential regional resources nationally, increasing industrial competitiveness based on superior resources owned by the region and increased value added along the value chain. Industrial territories are carried out through the development of industrial growth centers, development of industrial allotments, development of industrial estates; and the development of small and medium industry centers that are regulated by Government Regulations.

\section{The Development Policy Direction and Industrial Empowerment.}

The development policy direction and industrial empowerment in Indonesia normatively include; 1) empowering small and medium industries; 2) green industry; 3) strategic industries; 3) increasing use of domestic products; 4) international cooperation in the industrial sector. How to shape and realize the direction of development policy and industrial empowerment will be described as follows.

The expected characteristics of small and medium industries are competitiveness, significant role in strengthening the structure of the national industry, playing a role in poverty alleviation through expanding employment opportunities, producing industrial goods and / or services for export. In achieving the objectives of small and medium industries, the government and / or regional governments will do various things namely; a) formulating policies; b) strengthening institutional capacity and; c) providing facilities.

The form of policy priority on the development of small and medium industries can be carried out by the minister in charge of industry with an emphasis on aspects of regional industrial resources, strengthening and deepening the structure of the national industry, national and global economic development.

While the form of institutional capacity strengthening is carried out by the government and / or regional government in accordance with its capacity through: a) increasing the ability of centers, technical service units, field extension workers, and consultants for small and medium industries; b) collaboration with educational institutions, research and 
development institutions, as well as industry associations and related professional associations.

Likewise, in the case of the provision of facilities provided by the government and / or regional government in the form of access to finance, the initial capital utilization for new entrepreneurs in the form of; a) improvement of human resource competencies and competency certification; b) technical assistance and guidance; c) raw material and supporting material assistance; d) machinery or equipment assistance; e) product development; f) assistance to prevent environmental pollution to create a green industry; g) information, promotion and marketing assistance; $h$ ) access to finance, including authorizing the provision of initial capital for new entrepreneurs; i) provision of small and medium industrial areas that have the potential to pollute the environment; j) development and strengthening the linkages and partnership relationships between small and medium industries. Small industry with large industry, and medium industry with large industry, as well as small industry and medium industry with other sectors with the principle of mutual benefit.

While in realizing the green industry, the government is carrying out policy formulation, strengthening institutional capacity, standardization and providing facilities. The form of institutional capacity strengthening is carried out by relevant ministers and ministers, leaders of non-ministerial government institutions and local governments (taking into account input from relevant stakeholders) in the form of capacity building in research and development, testing, certification, promotion.

In carrying out standardization of the green industry carried out by the Minister, it must at least contain provisions regarding: a) raw materials, auxiliary materials and energy; b) the production process; c) products; d) business management; e) waste management. In the preparation of green industry standards, it is carried out by taking into account the standardization system and / or other applicable standard systems, coordinating with ministries and / or non-ministerial government agencies that carry out government affairs in the field of environment, research and technology, standardization and coordinating with industry associations, industrial companies and related institutions so that they become guidelines for industrial companies. The application of standardization is carried out gradually imposed compulsorily by the minister to industrial companies. If an industrial company does not meet green industry standards, administrative sanctions will be in the form of written warnings, administrative fines, temporary closures, freezing of industrial business licenses and revocation of licenses. 
Green industry companies that have fulfilled the requirements will be given a Green Industry certification by an accredited Green Industry certification body subject to the minister. To realize the green industry, industrial companies gradually build joint commitments and develop company policies for green industry development, implement policies, implement environmentally friendly management systems, develop business networks in obtaining raw materials, supporting materials and environmentally friendly technologies.

The State Ministry in Eka NAM Sihombing (2018) stated that justice is a basic human right that should be respected and guaranteed to be fulfilled. Access to justice in essence focuses on two objectives of the existence of a legal system, namely the legal system should be able to produce provisions and decisions that are fair to all people, both individually and in groups. ${ }^{8}$

Hart's thoughts lead to laws made based on the existence of an authorized authority to regulate people's lives. Legal authority lies because of the commands and sanctions that have causality. ${ }^{9}$

8 Eka N.A.M Sihombing, Mendorong Pembentukan Peraturan Daerah tentang Bantuan Hukum di Provinsi Sumatera Utara (Encourage of Establishing Regional Regulation Concerning Legal Aid at Province of North Sumatera), Jurnal Rechtvinding, Vol. 7, No. 3, December (2018).
Sudargo Gautama in Hadita (2018) According to the theory of basic norms (grundnorm), when asked why a person must submit and follow a government regulation, the answer is for example because the government regulation is in accordance with or is an order of the law made by parliament. And, why does one have to submit to and follow the law orders made by the parliament, then the answer is because it is an order from the constitution, which gives parliament the authority to make laws and orders the people to obey those laws created by the parliament. So, all legal rules that apply to the people must originate from the constitution which Hans Kelsen calls the basic norm (grundnorm), which contains fundamental norms to regulate human behavior through law enforcement. ${ }^{10}$

The strategic industries are controlled by the State to meet the needs that are important for the welfare of the people or control the livelihoods of many people in improving or producing value-added strategic natural resources and / or having links with the interests of national defense and security. The

${ }^{9}$ Cynthia Hadita, Registrasi Data Pribadi Melalui Kartu Prabayar Dalam Perspektif Hak Asasi Manusia (Provision of Personal Information in Prepaid SIM Card Registration from Human Rights Perspective), Jurnal HAM, Vol. 9, No. 2, December (2018).

${ }^{10} \mathrm{Ibid}$. 
form of control of strategic industries by the State is carried out through ownership arrangements, policy making, licensing arrangements, production, distribution and price arrangements as well as supervision. Strategic industrial ownership arrangements are carried out through full capital participation by the government, the establishment of joint ventures between the government and the private sector or restrictions on ownership by foreign investors. Determination of strategic industry policies which include determining the types of strategic industries, providing facilities and providing compensation for losses. The granting of a strategic business permit is granted by the minister while the regulation of production, distribution, and price is carried out by setting the amount of production, distribution and price of the product as well as supervision of strategic industries as a national vital object and distribution supervision.

As an effort to increase the use of domestic products, it is carried out by empowering domestic industries by requiring use of; a) State institutions, ministries, nonministerial government agencies and regional work units in the procurement of goods / services whose financing comes from the state budget and regional revenue, regional budget and revenue, including loans or grants from within or outside the country; b) state-owned business entities, regionally-owned business entities, private-owned business entities in the procurement of goods / services whose financing comes from the state revenue and expenditure budget, regional income and expenditure budget and / or their work is carried out through a pattern of cooperation between the government and the business entity private sector and / or cultivate resources controlled by the State. Any violation of the use of domestic products by goods / service procurement officials is subject to administrative sanctions in the form of written warnings, administrative fines, and / or termination of goods / services procurement positions.

The form of international cooperation in the industrial sector is aimed at opening access and developing international markets, opening access to industrial resources, utilizing the global supply chain network as a source of increasing industrial productivity and increasing investment. In conducting international cooperation in the industrial field, the government can draw up a strategic plan, determine steps to save the industry and / or provide facilities and if it is in the industry, consult with, coordinate and / or with the minister's approval. Specifically related to the granting of international cooperation facilities in the field of industry including guidance, consultation and advocacy, negotiation assistance, industry promotion and ease of flow of goods. The Government in an effort to 
increase international cooperation in the field of Industry can place industrial officials outside the country based on the need to increase the resilience of domestic industries or assign representatives of the Republic of Indonesia outside to enhance international cooperation in the industry sector by submitting periodic reports to the Minister.

\section{CONCLUSION}

Industrial law requires the formation of a national economic structure through industrialization activities by turning industrial resources into goods that have high benefits in an effort to realize the maximum welfare for the prosperity of the people. The policy direction of development and industrial empowerment must be taken seriously and achieve the expected goals of the small and medium industry sector, green industry, strategic industries, the use of domestic products and international cooperation. Industrial law must provide protection to the community against various national economic activities in the industrialization effort, not only prioritizing the interests of the company so that the objectives of industrialization can be met as a whole. In determining the direction of development policy and industrial empowerment, the government and or regional government have enormous authority to regulate and foster various industrial activities so that the government's alignments with the people must be prioritized.

\section{REFERENCES}

Hadita, Cynthia., Regional Autonomy Political Politics Of Regional Liability Reports To Regional Representatives In The Implementation Of Local Government, Nomoi Law Review, Volume 1, Issue 1, May 2020, p. 93.

Hadita, Cynthia., Registrasi Data Pribadi Melalui Kartu Prabayar Dalam Perspektif Hak Asasi Manusia (Provision of Personal Information in Prepaid SIM Card Registration from Human Rights Perspective), Jurnal HAM, Vol. 9, No. 2, December (2018).

Kodiyat MS, Benito Asdhie., Fungsi Partai Politik Dalam Meningkatkan Partsipasi Pemilih Pada Pemilihan Umum Kepala Daerah Di Kota Medan, JurnalEduTech, Vol. 5, No.1 Maret 2019, p. 7.

Manan, Abdul. Makalah Peranan Hukum dalam Pembangunan Ekonomi (Legal Role Paper in Economic Development), (2012).

Sihombing,Eka N.A.M, Mendorong Pembentukan Peraturan Daerah tentang Bantuan Hukum di Provinsi Sumatera Utara (Encourage of Establishing Regional Regulation Concerning Legal Aid at Province of North 
Sumatera),

Jurnal

Rechtvinding, Vol. 7, No. 3, December (2018).

Sihombing,Eka N.A.M., Cynthia

Hadita, Analisis Wacana

Hukuman Pancung Di

Provinsi Aceh, Jurnal

Legislasi Indonesia, Vol. 6,

No. 4, December (2019).

Syaputra, Muhammad Yusrizal Adi., Dani Sintara,Revitalization of Malay Cultural Values in Regional Regulation of Spatial and Region in Medan City. Budapest International Research and Critics Institute-Journal (BIRCI-Journal) Vol. 2, No. 3, August 2019, p. 355.

Yudhistira, Bhima. Sektor Industri Masih Hadapi Banyak Permasalahan Struktural (Industrial Sector Still Faces Many Structural Problems), https://ekonomi.bisnis.com/re $\mathrm{ad} / 20180331 / 257 / 778398 / \mathrm{sek}$ tor-industri-masih-hadapibanyak-permasalahanstruktural.

Peraturan Pemerintah Nomor 14 Tahun 2015 tentang Rencana Induk Pembangunan Industri Nasional Tahun 2015-2035. (Government Regulation Number 14 of 2015 concerning the National Industrial Development Master Plan 2015-2035.)

Peraturan Pemerintah Nomor 29 Tahun 2018 tentang Pemberdayaan Industri (Government Regulation Number 29 Year 2018 concerning Industrial Empowerment)
Peraturan Pemerintah Nomor 41 Tahun 2015 tentang Sumber Daya Industri (Government Regulation Number 41 of 2015 concerning Industrial Resources)

Peraturan Pemerintah Republik Indonesia Nomor 142 Tahun 2015 Tentang Kawasan Industri (Republic of Indonesia Government Regulation Number 142 Year 2015 Regarding Industrial Estates)

Peraturan Presiden Republik Indonesia Nomor 2 Tahun 2018 tentang Kebijakan Industri Nasional Tahun 2015-2019. (Presidential Regulation of the Republic of Indonesia Number 2 of 2018 concerning National Industrial Policy 2015-2019.)

Undang-Undang Nomor 3 Tahun 2014 tentang Perindustrian (Law Number 3 of 2014 concerning Industry) 